\title{
Twenty-Years of Hop Irrigation by Flooding the Inter-Row Did Not Cause a Gradient along the Row in Soil Properties, Plant Elemental Composition and Dry Matter Yield
}

\author{
Sandra Afonso ${ }^{1,2}$, Margarida Arrobas ${ }^{1}$ and Manuel Ângelo Rodrigues $1, *(\mathbb{D})$ \\ 1 Centro de Investigação de Montanha, Instituto Politécnico de Bragança, Campus de Santa Apolónia, \\ 5300-253 Bragança, Portugal; sandraafonso@ipb.pt (S.A.); marrobas@ipb.pt (M.A.) \\ 2 Faculdade de Ciências, Universidade do Porto, Rua do Campo Alegre, s/n, 4169-007 Porto, Portugal \\ * Correspondence: angelor@ipb.pt; Tel.: +351-273303260
}

Citation: Afonso, S.; Arrobas, M.; Rodrigues, M.Â. Twenty-Years of Hop Irrigation by Flooding the Inter-Row Did Not Cause a Gradient along the Row in Soil Properties, Plant Elemental Composition and Dry Matter Yield. Horticulturae 2021, 7, 194. https://doi.org/10.3390/ horticulturae7070194

\section{Academic Editors: Jolanta}

Jaroszuk-Ściseł, Małgorzata

Majewska and Agnieszka Hanaka

Received: 18 June 2021

Accepted: 13 July 2021

Published: 15 July 2021

Publisher's Note: MDPI stays neutral with regard to jurisdictional claims in published maps and institutional affiliations.

Copyright: (c) 2021 by the authors. Licensee MDPI, Basel, Switzerland. This article is an open access article distributed under the terms and conditions of the Creative Commons Attribution (CC BY) license (https:// creativecommons.org/licenses/by/ $4.0 /)$.

\begin{abstract}
In hops (Humulus lupulus L.), irrigation by flooding the inter-row can carry away suspended particles and minerals, causing gradients in soil fertility. The effect of more than 20 years of flooding irrigation on soil and plants was evaluated in two hop fields by measuring soil and plant variables in multiple points along the rows. In a second experiment $1000 \mathrm{~kg} \mathrm{ha}^{-1}$ of lime was applied and incorporated into the soil to assess whether liming could moderate any gradient created by the irrigation. At different sampling points along the rows, significant differences were recorded in soil properties, plant elemental composition and dry matter yield, but this was not found to exist over a continuous gradient. The variations in cone yield were over $50 \%$ when different sampling points were compared. However, this difference cannot be attributed to the effect of irrigation, but rather to an erratic spatial variation in some of the soil constituents, such as sand, silt and clay. Flooding irrigation and frequent soil tillage resulted in lower porosity and higher soil bulk density in the $0.0-0.10 \mathrm{~m}$ soil layer in comparison to the $0.10-0.20 \mathrm{~m}$ layer. In turn, porosity and bulk density were respectively positively and negatively associated with crop productivity. Thus, irrigation and soil tillage may have damaged the soil condition but did not create any gradient along the row. The ridge appeared to provide an important pool of nutrients, probably caused by mass flow due to the evaporation from it and a regular supply of irrigation water to the inter-row. Liming raised the soil $\mathrm{pH}$ slightly, but had a relevant effect on neither soil nor plants, perhaps because of the small amounts of lime applied.
\end{abstract}

Keywords: Humulus lupulus L.; soil porosity; soil bulk density; liming; hop ridges

\section{Introduction}

Hop plants (Humulus lupulus L.) require an adequate supply of water during the growing season to sustain their huge canopy [1]. In most of the hop producing regions of the world, the crop needs to be irrigated, particularly in lower latitudes of reduced precipitation in summer. Although hop fields have started to be drip irrigated all over the world, there is a long tradition of surface watering of this crop, by flooding the space between rows [1,2]. In this kind of surface or furrow irrigation system, water is applied at the top end of each furrow (in hops to the inter-row space) and flows down the field under the influence of gravity [3]. This is still the most commonly used irrigation method for hops in northern Portugal [4]. The water use efficiency with this irrigation technique is highly dependent on the field gradient and water infiltration rate, which can vary considerably, inducing spatial and temporal variability in the main soil properties [5]. In addition, flood irrigation can affect the spatial distribution of soil physicochemical properties which may exacerbate the spatial variability in crop growth and yield [6].

Flood irrigation can have a major impact on soil properties by varying salinity, redox potential, compaction and/or porosity [7-10]. Furthermore, hop fields which are 
flood-irrigated need to be frequently tilled to control summer weeds and to reduce soil compaction and superficial crusts in the short term. This allows a better infiltration of water, but that can also have a negative impact on the soil in the long term [11,12]. Soil compaction, increased by furrow irrigation, may also reduce soil drainage and aeration, contributing to the reduction of soil redox potential which influences soil chemistry and plant nutrient availability $[10,13]$. The degree of compaction of a soil can be assessed by measuring some physical properties, such as bulk density and porosity [12,13]. As the soil becomes more compact, bulk density increases and soil porosity decreases, which reduces water and air diffusion into the soil [11,14]. In some hop fields in northern Portugal it was found that the decrease in soil redox potential, associated with an excess of water and/or poor drainage, was the main cause of the spatial variability found in crop growth and yield [4].

Soil $\mathrm{pH}$ is another relevant issue in hop production. The range of $\mathrm{pH}$ most suited for growing hops is considered to be between 5.7 and $7.5[15,16]$. The application of lime is recommended for acidic soils, and a positive relationship has been found between the increase in soil $\mathrm{pH}$ and hop yield $[15,17]$. However, the effect of liming on crops can also vary with the irrigation system. Some researchers have studied the influence of liming in rice under flooding conditions, since great interactions between flooding, soil acidity and nutritional disorders are usually found [18-20]. In hops, these interactions are less well known, or the response to liming, but it is believed that it may be relevant enough to be studied, since the crop continues to be irrigated by flooding in several parts of the world.

This study evaluated the variation in soil properties and nutritional status and the productivity of hop plants created along the rows by flooding irrigation. As a second line of study, the effect of the application of lime on soil properties and on hop nutritional status, growth and yield was evaluated, to ascertain if the application of lime could compensate for the variability created by the irrigation system. Both lines of study were carried out in commercial hop fields which had been flood-irrigated for over 20 years.

\section{Materials and Methods}

\subsection{General Experimental Conditions}

The field experiments were carried out during two growing seasons (2017 and 2018) on a commercial farm located in Pinela $\left(41^{\circ} 40^{\prime} 33.6^{\prime \prime} \mathrm{N} ; 6^{\circ} 44^{\prime} 32.7^{\prime \prime} \mathrm{W}\right)$, Bragança, north-eastern Portugal. A detailed location of field experiments is shown in Figure 1.

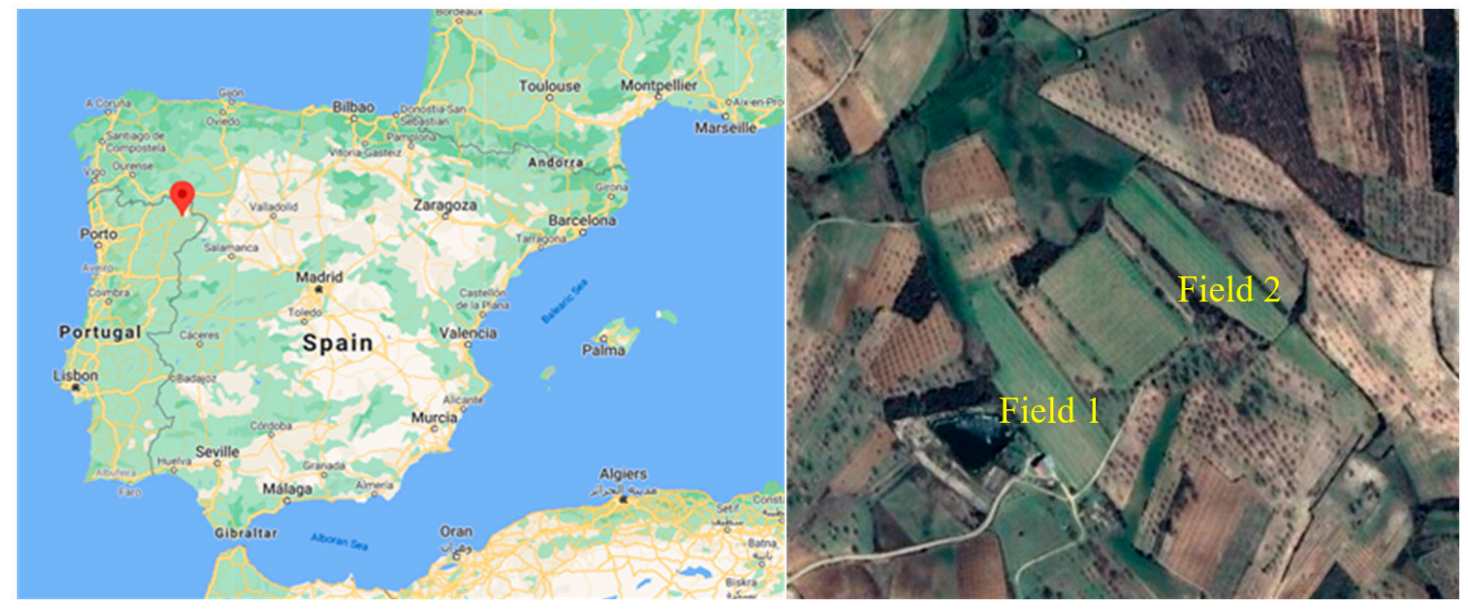

Figure 1. Map of Portugal indicating Pinela (left) and the two hop fields identified in this study as field 1 and field 2 (right). Images from https: / www.google.com/maps/place/Pinela (accessed on 7 July 2021).

The region benefits from a Mediterranean-type climate, with an annual average temperature and accumulated precipitation of $12.7^{\circ} \mathrm{C}$ and $772.8 \mathrm{~mm}$, respectively. The 
average monthly temperatures and precipitation recorded during the experimental period are shown in Figure 2.

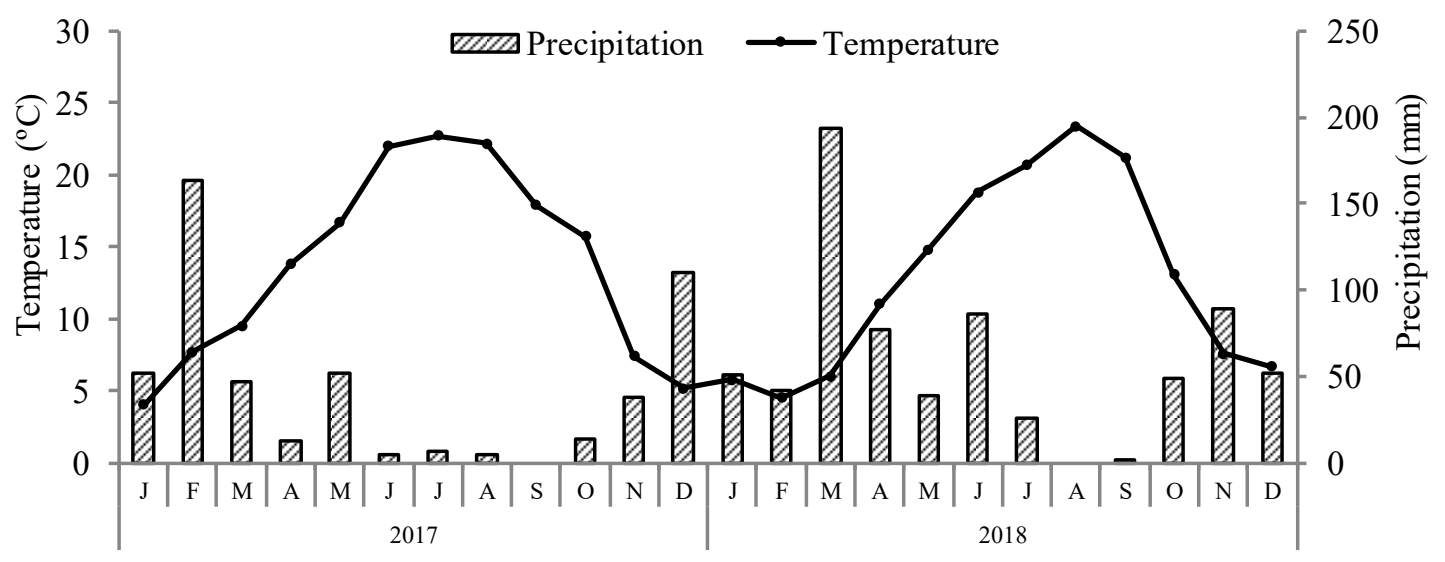

Figure 2. Average monthly temperatures and precipitation recorded during the experimental period at a weather station located in Bragança, north-eastern Portugal.

The hop plots where the study was undertaken are $\sim 2$ ha in size each, with the rows having a length ranging from 150 to $180 \mathrm{~m}$, and established with the cultivar Nugget. The fields are arranged in a $7 \mathrm{~m}$ conventional high trellis system, with concrete poles connected with steel cables, in a " $\mathrm{V}$ " design system. The farmer has managed the fields by flooding irrigation since the hop crop was installed more than 20 years ago. Several tillage passes ( 3 to 4 ) are performed every year to remove the crusts and facilitate water infiltration. The fertilization programme includes the application of a compound nitrogen $(\mathrm{N})$ : phosphorus $(\mathrm{P})$ : potassium $(\mathrm{K})$ fertilizer $\left(7: 14: 14,7 \% \mathrm{~N}, 14 \% \mathrm{P}_{2} \mathrm{O}_{5}, 14 \% \mathrm{~K}_{2} \mathrm{O}\right)$ early in the spring, followed by two applications of $\mathrm{N}$ fertilizer (ammonium nitrate, $27 \% \mathrm{~N}$ ) as a side-dressing, totalling $\sim 150,44$ and $83 \mathrm{~kg} \mathrm{ha}^{-1}$ of N, P and K, respectively. The farmer also follows a phytosanitary programme for crop protection against pests and diseases.

\subsection{Field Experiments and Soil and Plant Sampling}

The first experiment (Experiment 1) was carried out during the growing season of 2017 in two hop fields. It consisted of the evaluation of soil properties, plant nutritional status and crop yield, searching for any gradient along the rows created by the irrigation system. The rows used in this experiment were divided into nine segments of equivalent length, creating nine positions (P1, P2, . , P9) for soil and plant sampling. The soil was sampled between rows and on the ridges to a depth of 0.0 to $0.2 \mathrm{~m}$. Three rows and inter-rows of hops were used to create three replicates for each position. Each soil sample for analysis resulted from six sampling points (composite samples). The soil was sampled by using an open-face auger.

For the determination of soil bulk density and porosity, a different approach to soil sampling was followed. It was found unnecessary to sample in the ridges since no compaction was expected in this part. Instead, the soil was sampled at two different depths, 0.0 to $0.10 \mathrm{~m}$ and 0.10 to $0.20 \mathrm{~m}$. Due to the increased difficulty of sampling, particularly in the 0.10 to $0.20 \mathrm{~m}$ layer, only five positions were considered (P1, P3, P5, P7 and P9) and sampled in three replicates. For these analyses, undisturbed soil cores were taken by using appropriate cylinders of $100 \mathrm{~cm}^{3}$. Soil samplings were carried out on 10 March 2017.

The plants used in this experiment for the evaluation of their nutritional status and crop productivity were randomly selected and marked when plant height was close to $3 \mathrm{~m}$ (to avoid using very atypical plants) and close to each of the positions used for soil sampling. Leaf sampling for crop nutritional status assessment was done at $\sim 2 \mathrm{~m}$ in height, on 17 July 2017. At harvest (1 September 2017), plant biomass was cut at ground level. Subsequently, the aboveground biomass was separated into leaves, stems and cones 
and weighed fresh. Subsamples of each plant part were weighed fresh again and then oven-dried at $70{ }^{\circ} \mathrm{C}$ and weighed dry for determination of dry matter yield.

The second experiment (Experiment 2) consisted of the application of $1000 \mathrm{~kg} \mathrm{ha}^{-1}$ of lime ( $55 \% \mathrm{CaCO}_{3}, 28 \% \mathrm{CaO}$ and $20 \% \mathrm{MgO}$ ) in February 2017, to assess the liming effects on soil properties and plants in comparison to the untreated control. This experiment was also carried out in two hop plots. The general methodology for soil and plant sampling was similar to that reported for Experiment 1, consisting of marking nine positions along the rows. The soil was sampled on 4 January 2019 , only between the rows, at $0.0-0.20 \mathrm{~m}$ soil depth, using an open-face auger. Leaf samples were taken at $2 \mathrm{~m}$ in height, on 17 July 2017 and 18 July 2018. At harvest (1 September 2017 and 31 August 2018), plant biomass was cut at ground level and treated as reported for Experiment 1.

\subsection{Laboratory Analyses}

The undisturbed soil samples from Experiment 1 were oven-dried at $105{ }^{\circ} \mathrm{C}$ and weighed. Soil bulk density was estimated from the weight of dry soil divided by the volume of the cylinder. Soil porosity was determined as the ratio of nonsolid volume (soil particle density-bulk density) to the total volume of soil (soil particle density) [21]. The other soil samples from Experiments 1 and 2 were oven-dried at $40{ }^{\circ} \mathrm{C}$ and sieved in a mesh of $2 \mathrm{~mm}$. The samples were analysed for $\mathrm{pH}\left(\mathrm{H}_{2} \mathrm{O}\right.$ and $\left.\mathrm{KCl}\right)$, electrical conductivity (soil:solution, 1:2.5), exchangeable complex (ammonium acetate, $\mathrm{pH}$ 7.0) and organic carbon $(\mathrm{C})$ (Walkley-Black method). Extractable $\mathrm{P}$ and $\mathrm{K}$ were determined by a combination of ammonium lactate and acetic acid buffered at $\mathrm{pH}$ 3.7. Soil boron (B) was extracted by hot water and the extracts analysed by the azomethine-H method. More details of these analytical procedures are given in Van Reeuwijk [22]. Other micronutrients [copper (Cu), iron $(\mathrm{Fe})$, zinc $(\mathrm{Zn})$, and manganese $(\mathrm{Mn})]$ were determined by atomic absorption spectrometry after extraction with ammonium acetate and EDTA, following the methodology reported by Lakanen and Erviö [23].

Tissue samples (leaves, stems and cones) from both experiments were oven-dried at $70{ }^{\circ} \mathrm{C}$ and ground. Elemental tissue analyses were performed by Kjeldahl (N), colorimetry (B and $\mathrm{P})$, flame emission spectrometry $(\mathrm{K})$ and atomic absorption spectrophotometry (calcium $(\mathrm{Ca})$, magnesium $(\mathrm{Mg}), \mathrm{Cu}, \mathrm{Fe}, \mathrm{Zn}$ and $\mathrm{Mn}$ ) methods after nitric digestion of the samples [24].

\subsection{Data Analysis}

Data was subjected to analysis of variance, according to the experimental designs, using SPSS program version 25 . When significant differences were found between the experimental treatments, the means were separated by the Tukey HSD (sampling position) and Student's- $t$ (field, sampling site, lime treatment) tests $(\alpha=0.05)$. Linear regression analysis was performed to understand the effects of gradient on soil properties and plant nutritional status and productivity in Experiment 1 and the relationship between soil $\mathrm{pH}$ and plant variables in Experiment 2. The relation between the variables was obtained through correlation analysis with the Pearson coefficient, when the assumption of normality and linearity was accomplished; when this was not the case, the Spearman coefficient was used.

\section{Results}

\subsection{Gradients in Soil and Plants along the Rows}

\subsubsection{Soil Properties}

The silt and sand contents varied significantly between the sampling positions (Table 1). The two fields also differed significantly in clay and sand content. The soil bulk density and soil porosity varied significantly between the sampling positions and fields but in the opposite way. The interaction between sampling position and field was significant for soil porosity, which means that the effect of the irrigation on this variable depended on the field. 
Table 1. Soil separates and soil bulk density and porosity from samples collected at 0.0-0.20 m depth, in March 2017, as a function of sampling position $(1, \ldots, 9)$, and field. Means followed by the same letter are not significantly different by Tukey HSD (sampling position) or Student's $t$ (field) tests $(\alpha=0.05)$.

\begin{tabular}{cccccc}
\hline & Clay & $\begin{array}{c}\text { Silt } \\
\mathbf{( \% )}\end{array}$ & Sand & $\begin{array}{c}\text { Bulk Density } \\
\left(\mathbf{k g ~ d m}^{-3}\right)\end{array}$ & $\begin{array}{c}\text { Porosity } \\
\mathbf{( \% )}\end{array}$ \\
\hline Sampling position (P) & & & & & \\
Lowest value & $15.6 \mathrm{a}$ & $34.5 \mathrm{a}$ & $59.7 \mathrm{a}$ & $1.26 \mathrm{a}$ & $52.1 \mathrm{a}$ \\
Highest value & $11.8 \mathrm{a}$ & $28.5 \mathrm{~b}$ & $49.9 \mathrm{~b}$ & $1.18 \mathrm{~b}$ & $48.0 \mathrm{~b}$ \\
Field (F) & & & & & \\
Field 1 & $16.0 \mathrm{a}$ & $33.2 \mathrm{a}$ & $50.8 \mathrm{~b}$ & $1.25 \mathrm{a}$ & $59.1 \mathrm{~b}$ \\
Field 2 & $11.5 \mathrm{~b}$ & $32.1 \mathrm{a}$ & $56.4 \mathrm{a}$ & $1.21 \mathrm{~b}$ & 0.0020 \\
Prob (P) & 0.2770 & 0.0386 & 0.0307 & 0.0143 & 0.0259 \\
Prob (F) & 0.0005 & 0.3741 & 0.0072 & 0.0260 & 0.0256 \\
Prob (P $\times$ F) & 0.8998 & 0.0432 & 0.1221 & 0.0874 & \\
\hline
\end{tabular}

The soil bulk density was higher in the soil surface $(0.0-0.1 \mathrm{~m})$ when compared to the deeper $(0.1-0.2 \mathrm{~m})$ layer (Figure 3$)$. The soil bulk density did not vary significantly along the rows for both soil depths. The soil porosity, in turn, was lower in the surface layer, and the gradient found along the rows was not significant for any of the soil layers. The soil bulk density and porosity varied significantly between the two fields, but the gradients found along the rows were not statistically significant.
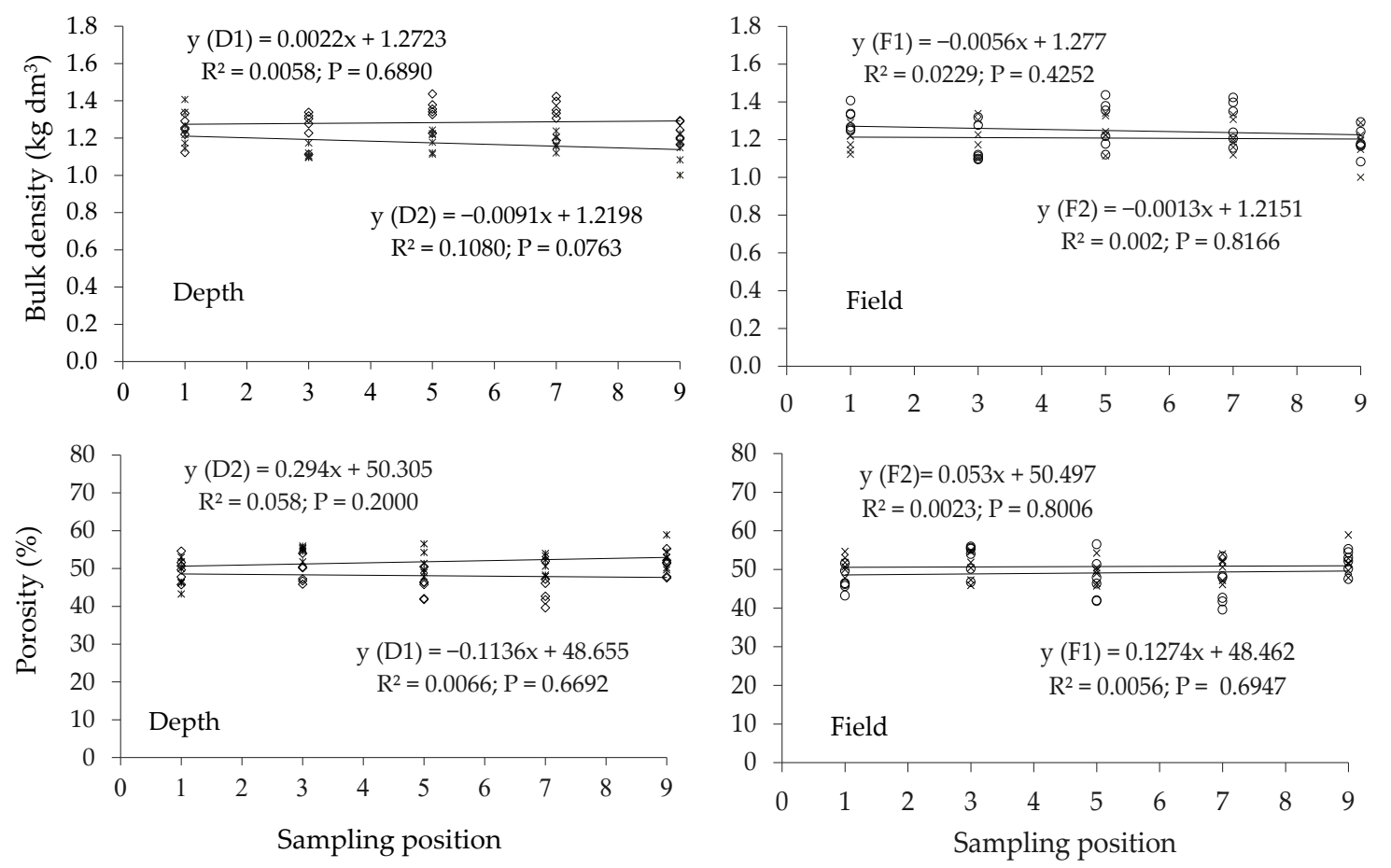

Figure 3. Soil bulk density and porosity from soil samples taken at different sampling positions along the gradient of irrigation $(1, \ldots, 9)$, as a function of depth (D1, 0.0-0.10 m; D2, 0.10-0.20 m) and field (F1, field 1; F2, field 2).

Some other soil properties determined from the samples collected at $0.0-0.20 \mathrm{~m}$ depth varied significantly between sampling sites, sampling positions and fields (Table 2). Extractable $\mathrm{P}$ and $\mathrm{K}$, conductivity, organic $\mathrm{C}, \mathrm{CEC}$ and extractable $\mathrm{Zn}$ and $\mathrm{B}$ showed significantly higher values in the samples collected in the ridges. However, soil $\mathrm{pH}\left(\mathrm{H}_{2} \mathrm{O}\right.$ and $\mathrm{KCl}$ ), base saturation and extractable $\mathrm{Mn}$ were significantly higher in the samples collected in the inter-rows. Most of the soil properties varied significantly between the sampling positions, the exceptions being soil $\mathrm{pH}$, conductivity and extractable $\mathrm{K}$. Soil properties also differed significantly between fields, except for soil conductivity. Significant 
interaction between the sampling site and the field was found for extractable $\mathrm{P}$, conductivity, exchangeable $\mathrm{Ca}$ and extractable Fe. Significant interaction between the sampling position and the field was found for organic $\mathrm{C}$ and extractable $\mathrm{Fe}, \mathrm{Mn}, \mathrm{Zn}, \mathrm{Cu}$ and $\mathrm{B}$. No significant interaction was found between the three factors of this experiment.

\subsubsection{Hop Dry Mater Yield and Leaf Nutrient Concentration}

Aboveground dry biomass (stems, leaves, cones and total) in Field 1 showed a clear tendency for a decrease along the rows (Figure 4). However, the decrease was only statistically significant for stem dry matter yield (DMY). For all plant parts, the coefficients of determination $\left(R^{2}\right)$ were not particularly high, which helps to explain the lack of significant correlation between the two variables. In Field 2, no clear tendency was found in aboveground DMY.
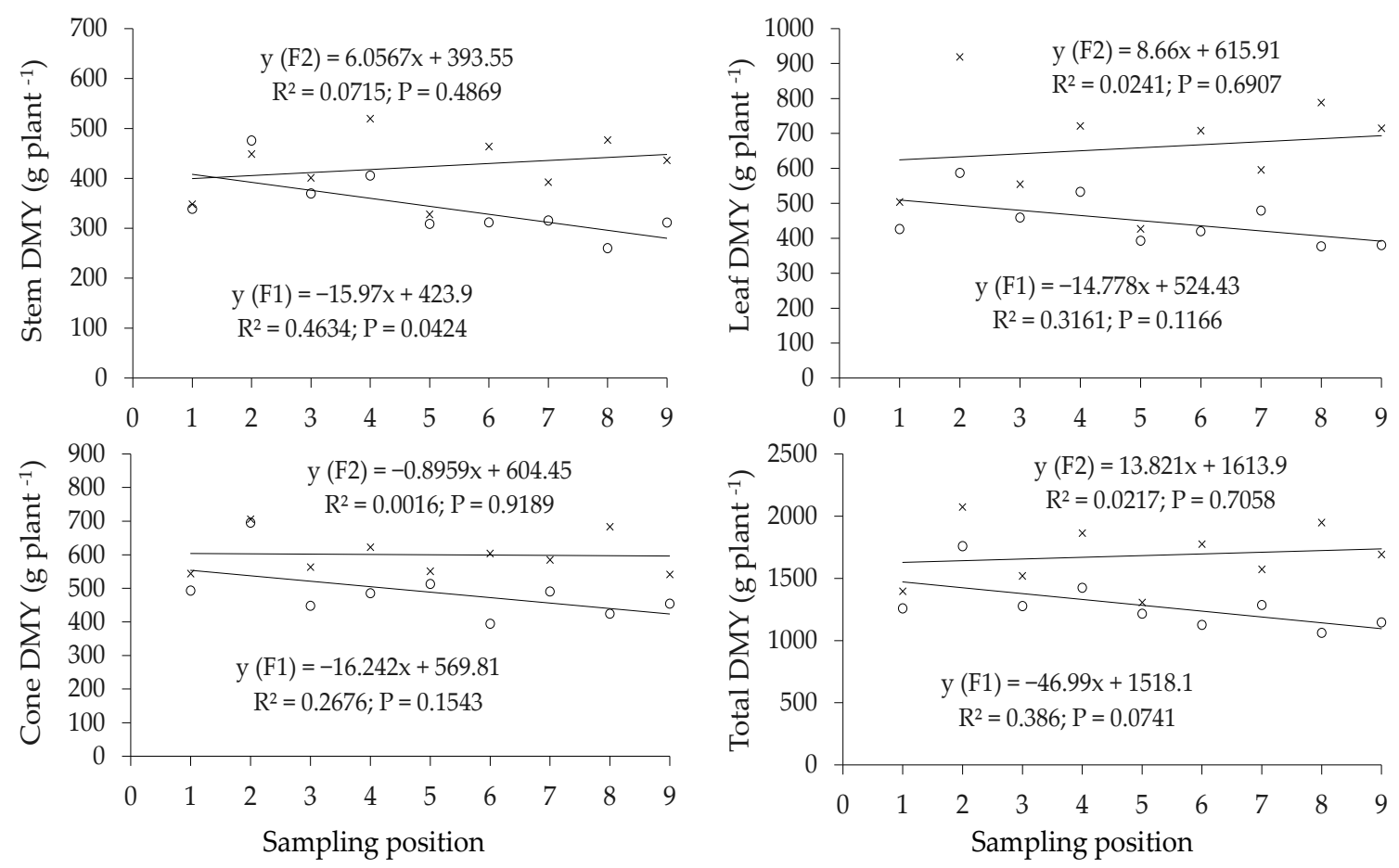

Figure 4. Dry matter yield (DMY) from plants collected at harvest in September 2017, at different sampling positions along the gradient of irrigation $(1, \ldots, 9)$, and as a function of field (F1, field 1; F2, field 2).

$\mathrm{N}$ concentration in the leaves taken at $2 \mathrm{~m}$ height did not vary significantly along the rows in any of the fields (Figure 5). Leaf $\mathrm{P}$ also did not vary significantly along the rows but the values in Field 1 were lower than in Field 2. Leaf K levels did not vary significantly along the rows in Field 1 but increased significantly in Field 2. Leaf $\mathrm{Ca}$ and $\mathrm{Mg}$ levels showed a slight tendency to increase in both fields but without statistical significance. In general, the micronutrients showed even more erratic tendencies when the values of the two fields were compared and only the values of leaf $\mathrm{Cu}$ showed a significant decrease along the rows in Field 1. 


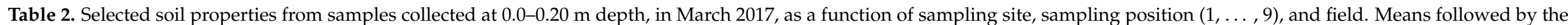
same letter are not statistically different by Tukey HSD (Sampling position) or Student's $t$ (Sampling site and Field) tests $(\alpha=0.05)$.

\begin{tabular}{|c|c|c|c|c|c|c|c|c|c|c|c|c|c|c|}
\hline & $\begin{array}{c}\text { Extract. } \mathrm{K} \\
\left(\mathrm{mg} \mathrm{K}_{2} \mathrm{O}\right. \\
\left.\mathrm{kg}^{-1}\right)^{1}\end{array}$ & $\begin{array}{l}\text { Extract. P } \\
\left(\mathrm{mg} \mathrm{P}_{2} \mathrm{O}_{5}\right. \\
\left.\mathrm{kg}^{-1}\right)^{1}\end{array}$ & $\begin{array}{l}\text { Conductivity } \\
(\mu \mathrm{s} / \mathrm{m})\end{array}$ & $\mathrm{pH}_{\mathrm{H}_{2} \mathrm{O}}$ & $\mathrm{pH}_{\mathrm{KCl}}$ & $\begin{array}{c}\text { Organic C } \\
\left(\mathrm{g} \mathrm{kg}^{-1}\right)\end{array}$ & $\begin{array}{l}\text { Exchan. Ca } \\
\qquad \text { (cmolc kg }\end{array}$ & CEC & $\begin{array}{c}\text { Base } \\
\text { Saturation } \\
(\%)\end{array}$ & Extract. Fe & $\begin{array}{c}\text { Extract. } \\
\text { Mn } \\
\text { (mg l }\end{array}$ & $\begin{array}{l}\text { Extract. } \\
\text { Zn }\end{array}$ & $\begin{array}{l}\text { Extract. } \\
\mathbf{C u}\end{array}$ & $\begin{array}{c}\text { Extract. B } \\
\left(\mathrm{mg} \mathrm{kg}^{-1}\right)^{4}\end{array}$ \\
\hline \multicolumn{15}{|l|}{ Sampling site (S) } \\
\hline Ridge & $310.4 \mathrm{a}$ & $349.7 \mathrm{a}$ & $78.9 \mathrm{a}$ & $5.42 \mathrm{~b}$ & $4.42 \mathrm{~b}$ & $20.9 \mathrm{a}$ & $4.94 \mathrm{a}$ & $7.34 \mathrm{a}$ & $87.7 \mathrm{~b}$ & $213.4 \mathrm{a}$ & $166.8 \mathrm{~b}$ & $5.03 \mathrm{a}$ & $7.86 \mathrm{a}$ & $1.16 \mathrm{a}$ \\
\hline \multicolumn{11}{|c|}{ Sampling position $(\mathrm{P})$} & $194.2 \mathrm{a}$ & $4.28 \mathrm{~b}$ & $7.84 \mathrm{a}$ & $0.79 \mathrm{~b}$ \\
\hline Lowest value & $228.3 \mathrm{a}$ & $195.0 \mathrm{c}$ & $60.2 \mathrm{a}$ & $5.42 \mathrm{a}$ & $4.35 \mathrm{a}$ & $17.8 \mathrm{~b}$ & $3.80 \mathrm{c}$ & $6.21 \mathrm{~b}$ & $86.0 \mathrm{~b}$ & $178.1 \mathrm{c}$ & $136.0 \mathrm{~d}$ & $3.47 \mathrm{~d}$ & $6.64 \mathrm{~d}$ & $0.79 \mathrm{c}$ \\
\hline $\begin{array}{l}\text { Highest value } \\
\text { Field (F) }\end{array}$ & $313.6 \mathrm{a}$ & $399.7 \mathrm{a}$ & $70.0 \mathrm{a}$ & $5.60 \mathrm{a}$ & $4.64 \mathrm{a}$ & $21.3 \mathrm{a}$ & $5.73 \mathrm{a}$ & $7.68 \mathrm{a}$ & $92.1 \mathrm{a}$ & $262.2 \mathrm{a}$ & $217.3 \mathrm{a}$ & $5.64 \mathrm{a}$ & $9.22 \mathrm{a}$ & $1.17 \mathrm{a}$ \\
\hline Field 1 & $361.8 \mathrm{a}$ & $286.3 \mathrm{~b}$ & $65.9 \mathrm{a}$ & $5.75 \mathrm{a}$ & $4.67 \mathrm{a}$ & $18.4 \mathrm{~b}$ & $5.22 \mathrm{a}$ & $7.31 \mathrm{a}$ & $93.6 \mathrm{a}$ & $207.2 \mathrm{~b}$ & $134.1 \mathrm{~b}$ & $4.96 \mathrm{a}$ & $10.35 \mathrm{a}$ & $0.91 \mathrm{~b}$ \\
\hline Field 2 & $195.1 \mathrm{~b}$ & $356.2 \mathrm{a}$ & $67.6 \mathrm{a}$ & $5.21 \mathrm{~b}$ & $4.27 \mathrm{~b}$ & $20.8 \mathrm{a}$ & $4.49 \mathrm{~b}$ & $6.66 \mathrm{~b}$ & $84.0 \mathrm{~b}$ & $228.4 \mathrm{a}$ & $226.8 \mathrm{a}$ & $4.35 \mathrm{~b}$ & $5.36 \mathrm{~b}$ & $1.04 \mathrm{a}$ \\
\hline Prob (S) & $<0.0001$ & 0.0022 & $<0.0001$ & 0.0028 & 0.0236 & $<0.0001$ & 0.4028 & 0.0069 & 0.0179 & 0.2836 & 0.0003 & 0.0009 & 0.9386 & $<0.0001$ \\
\hline $\operatorname{Prob}(\mathrm{P})$ & 0.0758 & $<0.0001$ & 0.9345 & 0.3221 & 0.0710 & 0.0058 & $<0.0001$ & 0.0268 & 0.0012 & $<0.0001$ & $<0.0001$ & $<0.0001$ & 0.0003 & 0.0007 \\
\hline Prob (F) & $<0.0001$ & 0.0002 & 0.5991 & $<0.0001$ & $<0.0001$ & $<0.0001$ & 0.0004 & 0.0130 & $<0.0001$ & 0.0100 & $<0.0001$ & 0.0070 & $<0.0001$ & 0.0075 \\
\hline $\operatorname{Prob}(\mathrm{S} \times \mathrm{P})$ & 0.6500 & 0.9648 & 0.9341 & 0.9859 & 0.7781 & 0.8954 & 0.7956 & 0.7826 & 0.0938 & 0.9836 & 0.0644 & 0.8658 & 0.2274 & 0.5881 \\
\hline $\operatorname{Prob}(S \times F)$ & 0.8057 & 0.0001 & 0.0013 & 0.8860 & 0.7597 & 0.7527 & 0.0287 & 0.1220 & 0.0901 & 0.0053 & 0.6578 & 0.0738 & 0.1982 & 0.0810 \\
\hline $\operatorname{Prob}(\mathrm{P} \times \mathrm{F})$ & 0.0904 & 0.0374 & 0.8663 & 0.1846 & 0.2467 & 0.0199 & 0.8269 & 0.6486 & 0.1179 & $<0.0001$ & $<0.0001$ & 0.0018 & $<0.0001$ & 0.0497 \\
\hline $\operatorname{Prob}(\mathrm{S} \times \mathrm{P} \times \mathrm{F})$ & 0.4096 & 0.9991 & 0.9791 & 0.5470 & 0.9433 & 0.5569 & 0.9503 & 0.9365 & 0.2005 & 0.9005 & 0.5541 & 0.6590 & 0.6793 & 0.4975 \\
\hline
\end{tabular}

${ }^{1}$ Egner-Rhiem; ${ }^{2}$ ammonium acetate, $\mathrm{pH} 7 ;{ }^{3}$ ammonium acetate and EDTA; ${ }^{4}$ azomethine-H. 

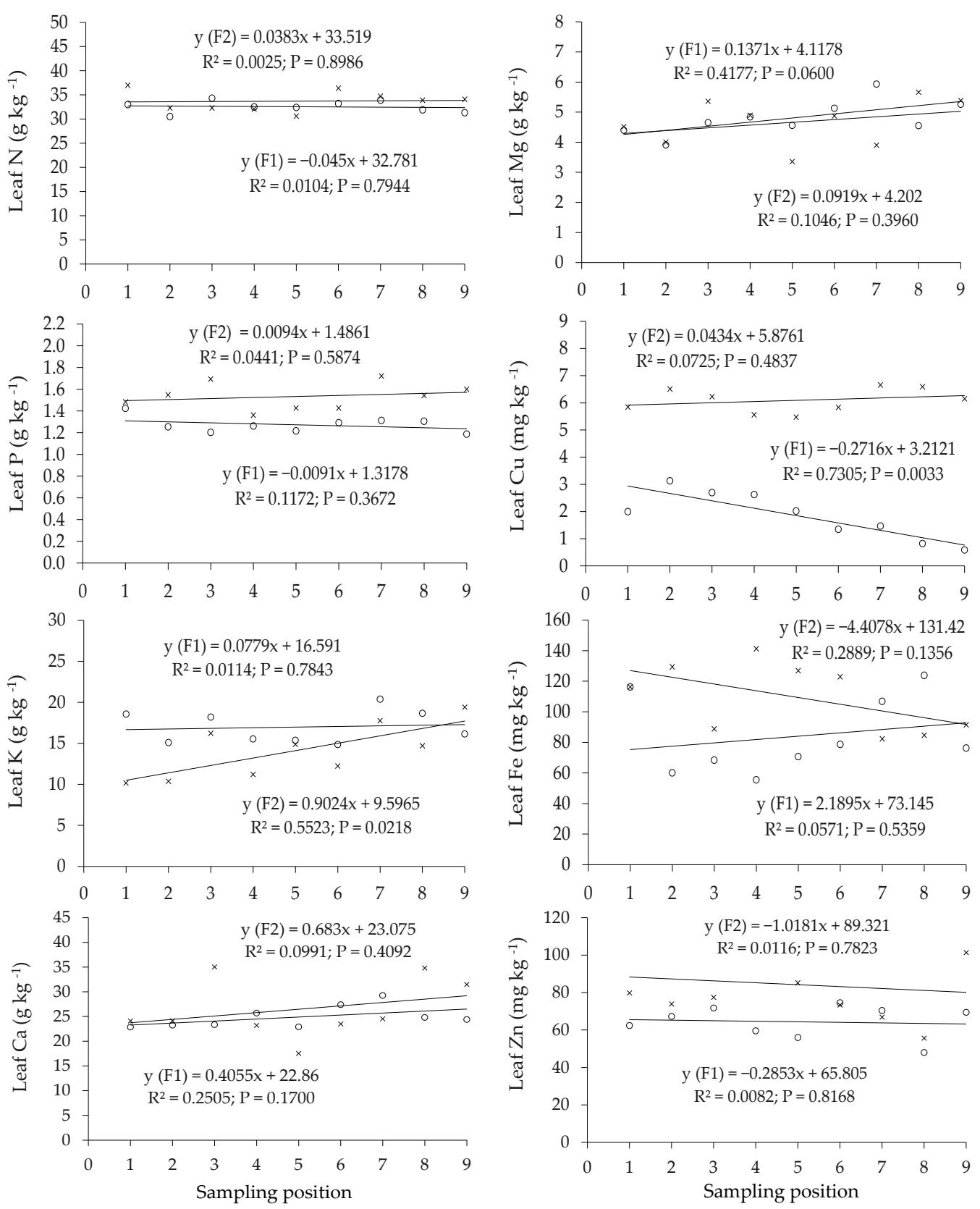

Figure 5. Leaf nutrient concentration from samples taken at $2 \mathrm{~m}$ height and at different sampling positions along the gradient of irrigation $(1, \ldots, 9)$, as a function of field (F1, field $1 ; \mathrm{F} 2$, field 2 ).

\subsubsection{Correlation Analysis between Soil Properties and Plant Dry Matter Yield}

Soil bulk density and porosity correlated in a different way with soil $\mathrm{pH}\left(\mathrm{H}_{2} \mathrm{O}\right.$ and $\mathrm{KCl}$ ), leaf $\mathrm{P}$ and total DMY (Table 3). That is, the correlations of soil $\mathrm{pH}$ were positive for soil bulk density and negative for soil porosity at $0.0-0.10 \mathrm{~m}$ depth. Leaf $\mathrm{P}$ concentration was significantly and negatively correlated with soil bulk density at $0.10-0.20 \mathrm{~m}$ depth, in contrast to the positive correlation found with soil porosity. Leaf Fe concentration was found significant and negatively correlated only with soil porosity at $0.10-0.20 \mathrm{~m}$ depth. The strongest correlations were found for total DMY with soil bulk density $(r=-0.706)$ and soil porosity $(\mathrm{r}=0.714)$, both at $0.10-0.20 \mathrm{~m}$ depth. 


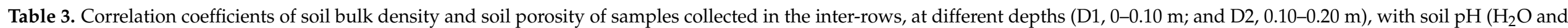
$\mathrm{KCl}$ ) and leaf nutrient concentrations from samples taken at $2 \mathrm{~m}$ height in July 2017, and total and cone dry matter yield (DMY) from plants collected in September 2017.

\begin{tabular}{|c|c|c|c|c|c|c|c|c|c|c|c|c|c|c|}
\hline & \multicolumn{2}{|c|}{ Soil $^{+}$} & \multirow[b]{2}{*}{$\mathbf{N}$} & \multirow[b]{2}{*}{$\mathbf{P}$} & \multicolumn{8}{|c|}{ Leaf Nutrient $^{+}$} & \multicolumn{2}{|c|}{ DMY } \\
\hline & \multirow{2}{*}{$\mathrm{pH}_{\mathrm{H}_{2} \mathrm{O}}$} & \multirow{2}{*}{$\mathrm{pH}_{\mathrm{KCl}}$} & & & $\mathbf{K}$ & $\mathrm{Ca}$ & Mg & $\mathrm{Fe}$ & Mn & $\mathrm{Cu}$ & Zn & B & Total $\ddagger$ & Cone $^{+}$ \\
\hline & & & \multicolumn{5}{|c|}{$\left(\mathrm{g} \mathrm{kg}^{-1}\right)$} & \multicolumn{5}{|c|}{$\left(\mathrm{mg} \mathrm{kg}^{-1}\right)$} & \multicolumn{2}{|c|}{ (g Plant $^{-1}$ ) } \\
\hline \multicolumn{15}{|l|}{ Soil bulk density } \\
\hline D1 (0.0-0.10 m depth) & $0.422 *$ & $0.440 *$ & -0.442 & -0.190 & 0.043 & -0.209 & -0.130 & 0.128 & -0.067 & -0.322 & -0.515 & -0.333 & -0.243 & 0.139 \\
\hline D2 (0.10-0.20 m depth) & 0.087 & 0.062 & -0.239 & -0.690 * & -0.046 & -0.512 & -0.249 & 0.626 & -0.220 & -0.525 & -0.312 & -0.459 & $-0.706^{*}$ & -0.128 \\
\hline \multicolumn{15}{|l|}{ Soil porosity } \\
\hline D1 (0.0-0.10 cm depth) & $-0.396^{*}$ & -0.400 * & 0.418 & -0.038 & -0.110 & 0.055 & 0.075 & -0.055 & 0.139 & 0.097 & 0.370 & 0.285 & 0.168 & -0.261 \\
\hline \multicolumn{15}{|l|}{ Soil separates } \\
\hline Clay & $0.806^{* *}$ & $0.542 *$ & -0.241 & $-0.563 *$ & $0.639 * *$ & 0.038 & 0.057 & -0.389 & -0.197 & $-0.773 * *$ & -0.459 & $-0.707^{* *}$ & $-0.676^{* *}$ & $-0.666^{* *}$ \\
\hline Silt & 0.387 & 0.129 & -0.220 & 0.066 & 0.323 & -0.049 & -0.084 & 0.042 & -0.292 & -0.179 & -0.042 & $-0.503^{*}$ & -0.117 & -0.005 \\
\hline Sand & $-0.703^{* *}$ & -0.391 & 0.276 & 0.339 & $-0.562 *$ & 0.034 & 0.046 & 0.247 & 0.300 & 0.571 * & 0.307 & $0.639 * *$ & 0.427 & 0.410 \\
\hline
\end{tabular}

Significant correlations at the correspondent levels of ${ }^{*} 0.05$ and ${ }^{* *} 0.01 ;{ }^{\dagger}$ Spearman and ${ }^{\ddagger}$ Pearson correlation coefficients. 
Significant correlations were found for soil clay content, positive for soil $\mathrm{pH}$ and leaf $\mathrm{K}$, and negative for leaf $\mathrm{P}$, leaf $\mathrm{Cu}$, total DMY and cone DMY. In contrast, soil sand content correlated significantly and negatively with soil $\mathrm{pH}\left(\mathrm{H}_{2} \mathrm{O}\right)$ and leaf $\mathrm{K}$, and positively with leaf $\mathrm{Cu}$ and $\mathrm{B}$. Soil silt content correlated significantly and negatively with leaf $\mathrm{B}$.

\subsection{Liming Experiment \\ 3.2.1. Soil Properties}

Most soil properties, such as extractable $\mathrm{K}, \mathrm{P}, \mathrm{Mn}, \mathrm{Zn}, \mathrm{Cu}, \mathrm{B}$, conductivity and $\mathrm{pH}$ presented significantly higher values in the limed plot in comparison to the untreated control (Table 4). Exchangeable Ca and CEC showed higher values in the limed plot but not significantly different to those observed in the control. Significant differences between the two fields used in this experiment were also found for most of the soil properties, the values of extractable $\mathrm{K}, \mathrm{P}, \mathrm{Zn}, \mathrm{Cu}$ and $\mathrm{B}$, conductivity, $\mathrm{pH}$, exchangeable $\mathrm{Ca}, \mathrm{CEC}$ and base saturation being significantly higher in Field 1. Only extractable Fe was significantly higher in Field 2. The interaction between liming and field was significant for extractable $\mathrm{K}$, conductivity, and $\mathrm{pH}$.

\subsubsection{Plant Response to Liming}

The concentration of nutrients in the leaves taken at $2 \mathrm{~m}$ height showed significant differences between treatments for leaf P in 2017 and for leaf Fe and B in 2018 (Table 5). The values reported for $\mathrm{P}$ and Fe were significantly higher in the limed plots, and those reported for B were significantly higher in the control. Total and cone DMY were significantly lower in the limed plots with the exception of total DMY in 2017, whose differences between treatments were not statistically significant. When comparing fields, significant differences were found for some nutrients and total and cone DMY. However, only leaf concentrations of $\mathrm{K}, \mathrm{Cu}$ and $\mathrm{B}$, and total and cone DMY, maintained the same trend in both years and fields. In 2017, significant interaction between the liming treatment and the field was only found for leaf $\mathrm{N}$ and $\mathrm{Mn}$ and in 2018 for leaf $\mathrm{P}$ and total DMY.

\subsubsection{Correlation Analysis between Soil $\mathrm{pH}$ and Plant Variables}

Significant correlations between the soil $\mathrm{pH}\left(\mathrm{H}_{2} \mathrm{O}\right.$ and $\left.\mathrm{KCl}\right)$ and leaf nutrient concentration were found for several nutrients, but a similar trend over the two years was found only for leaf $\mathrm{Cu}$ and $\mathrm{B}$, both presenting negative correlations with soil $\mathrm{pH}$ (Table 6). Soil $\mathrm{pH}$ and leaf $\mathrm{P}$, for instance, showed a negative correlation in 2017 and a positive correlation in 2018. Significant and negative relations between soil $\mathrm{pH}$ and total and cone DMY were also found for the first year of plant sampling. 


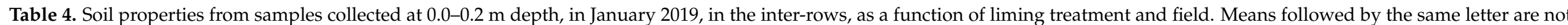
statistically different by Student's $t$ test $(\alpha=0.05)$.

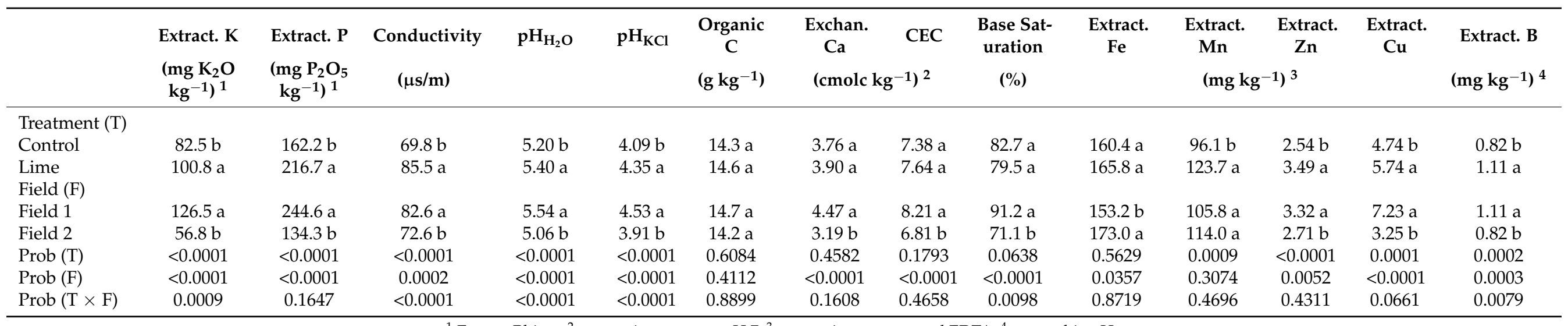

${ }^{1}$ Egner-Rhiem; ${ }^{2}$ ammonium acetate, $\mathrm{pH} 7 ;^{3}$ ammonium acetate and EDTA; ${ }^{4}$ azomethine-H.

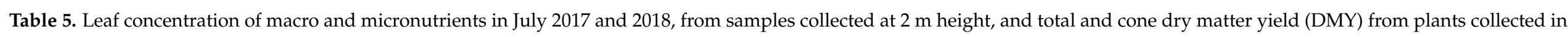
August 2017 and September 2018, as a function of liming treatment and field. Means followed by the same letter are not statistically different by Student's $t$ test ( $\alpha=0.05$ ).

\begin{tabular}{|c|c|c|c|c|c|c|c|c|c|c|c|c|c|}
\hline & & $\mathbf{N}$ & $\mathbf{P}$ & $\mathbf{K}$ & $\mathrm{Ca}$ & $\mathrm{Mg}$ & $\mathrm{Fe}$ & Mn & $\mathrm{Cu}$ & $\mathrm{Zn}$ & B & Total DMY & Cone DMY \\
\hline & & \multicolumn{5}{|c|}{$\left(\mathrm{g} \mathrm{kg}^{-1}\right)$} & \multicolumn{5}{|c|}{$\left(\mathrm{mg} \mathrm{kg}^{-1}\right)$} & \multicolumn{2}{|c|}{ (g Plant $\left.^{-1}\right)$} \\
\hline \multirow{9}{*}{ 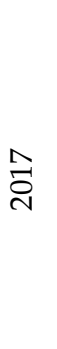 } & Treatment (T) & & & & & & & & & & & & \\
\hline & Control & $3.31 \mathrm{a}$ & $0.14 \mathrm{~b}$ & $1.56 \mathrm{a}$ & $2.57 \mathrm{a}$ & $0.47 \mathrm{a}$ & $96.7 \mathrm{a}$ & $374.1 \mathrm{a}$ & $3.97 \mathrm{a}$ & $74.3 \mathrm{a}$ & $71.7 \mathrm{a}$ & $1483 \mathrm{a}$ & $544.3 \mathrm{a}$ \\
\hline & Lime & $3.39 \mathrm{a}$ & $0.15 \mathrm{a}$ & $1.66 \mathrm{a}$ & $2.72 \mathrm{a}$ & $0.52 \mathrm{a}$ & $95.3 \mathrm{a}$ & 316.9 a & $4.59 \mathrm{a}$ & $82.9 \mathrm{a}$ & $69.3 \mathrm{a}$ & 1379 a & $441.2 \mathrm{~b}$ \\
\hline & Field (F) & & & & & & & & & & & & \\
\hline & Field 1 & $3.39 \mathrm{a}$ & $0.13 \mathrm{~b}$ & $1.76 \mathrm{a}$ & $2.56 \mathrm{a}$ & $0.49 \mathrm{a}$ & $87.9 \mathrm{~b}$ & 355.9 a & $2.54 \mathrm{~b}$ & $64.35 \mathrm{~b}$ & $63.29 \mathrm{~b}$ & $1271 \mathrm{~b}$ & $446.2 \mathrm{~b}$ \\
\hline & Field 2 & $3.31 \mathrm{a}$ & $0.16 \mathrm{a}$ & $1.46 \mathrm{~b}$ & $2.73 \mathrm{a}$ & $0.50 \mathrm{a}$ & $104.2 \mathrm{a}$ & $335.1 \mathrm{a}$ & $6.03 \mathrm{a}$ & $92.88 \mathrm{a}$ & $77.70 \mathrm{a}$ & 1591 a & $539.3 \mathrm{a}$ \\
\hline & Prob. (T) & 0.2043 & 0.0440 & 0.3130 & 0.3597 & 0.1445 & 0.8597 & 0.0703 & 0.2111 & 0.2636 & 0.2542 & 0.2139 & 0.0033 \\
\hline & Prob. (F) & 0.2180 & $<0.0001$ & 0.0049 & 0.2909 & 0.7214 & 0.0447 & 0.5024 & $<0.0001$ & 0.0007 & $<0.0001$ & 0.0005 & 0.0073 \\
\hline & Prob. $(\mathrm{T} \times \mathrm{F})$ & 0.0024 & 0.7290 & 0.8820 & 0.9293 & 0.4216 & 0.2588 & 0.0358 & 0.1327 & 0.2608 & 0.0918 & 0.3402 & 0.5728 \\
\hline
\end{tabular}


Table 5. Cont.

\begin{tabular}{|c|c|c|c|c|c|c|c|c|c|c|c|c|c|}
\hline & & $\mathbf{N}$ & $\mathbf{P}$ & $\mathbf{K}$ & $\mathrm{Ca}$ & Mg & $\mathrm{Fe}$ & Mn & $\mathrm{Cu}$ & $\mathrm{Zn}$ & B & Total DMY & Cone DMY \\
\hline & & \multicolumn{5}{|c|}{$\left(\mathrm{g} \mathrm{kg}^{-1}\right)$} & \multicolumn{5}{|c|}{$\left(\mathrm{mg} \mathrm{kg}^{-1}\right)$} & \multicolumn{2}{|c|}{$\left(\right.$ g Plant $\left.^{-1}\right)$} \\
\hline \multirow{9}{*}{$\stackrel{\infty}{\stackrel{\infty}{\sim}}$} & Treatment $(\mathrm{T})$ & & & & & & & & & & & & \\
\hline & Control & $3.48 \mathrm{a}$ & $0.19 \mathrm{a}$ & $3.26 \mathrm{a}$ & $1.53 \mathrm{a}$ & $0.56 \mathrm{a}$ & $94.6 \mathrm{~b}$ & $513.0 \mathrm{a}$ & $6.93 a$ & $21.0 \mathrm{a}$ & $57.5 \mathrm{a}$ & $1681 \mathrm{a}$ & $475.2 \mathrm{a}$ \\
\hline & Lime & $3.56 \mathrm{a}$ & $0.19 \mathrm{a}$ & $3.19 \mathrm{a}$ & $1.57 \mathrm{a}$ & $0.61 \mathrm{a}$ & $109.3 \mathrm{a}$ & $495.2 \mathrm{a}$ & $7.07 \mathrm{a}$ & $19.5 \mathrm{a}$ & $51.6 \mathrm{~b}$ & $1407 \mathrm{~b}$ & $380.2 \mathrm{~b}$ \\
\hline & Field (F) & & & & & & & & & & & & \\
\hline & Field 1 & $3.55 \mathrm{a}$ & $0.20 \mathrm{a}$ & $3.83 \mathrm{a}$ & $1.43 \mathrm{~b}$ & $0.62 \mathrm{a}$ & $91.0 \mathrm{~b}$ & $408.9 \mathrm{~b}$ & $6.26 \mathrm{~b}$ & $20.51 \mathrm{a}$ & $52.37 \mathrm{~b}$ & $1421 b$ & $428.9 \mathrm{a}$ \\
\hline & Field 2 & $3.49 \mathrm{a}$ & $0.17 \mathrm{~b}$ & $2.63 \mathrm{~b}$ & $1.67 \mathrm{a}$ & $0.55 \mathrm{~b}$ & $112.9 \mathrm{a}$ & $599.4 \mathrm{a}$ & $7.73 \mathrm{a}$ & $19.96 \mathrm{a}$ & $56.70 \mathrm{a}$ & $1666 \mathrm{a}$ & $426.4 \mathrm{a}$ \\
\hline & Prob. (T) & 0.2155 & 0.8374 & 0.6215 & 0.4655 & 0.0550 & 0.0035 & 0.7162 & 0.5532 & 0.1170 & 0.0024 & 0.0016 & 0.0021 \\
\hline & Prob. (F) & 0.3461 & $<0.0001$ & $<0.0001$ & 0.0001 & 0.0279 & $<0.0001$ & 0.0004 & $<0.0001$ & 0.5648 & 0.0218 & 0.0043 & 0.9304 \\
\hline & Prob. $(\mathrm{T} \times \mathrm{F})$ & 0.6601 & 0.0185 & 0.2051 & 0.0983 & 0.2205 & 0.9394 & 0.8796 & 0.6927 & 0.1228 & 0.4463 & 0.0057 & 0.3068 \\
\hline
\end{tabular}

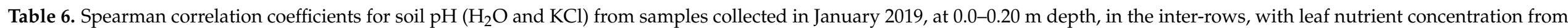
samples collected at $2 \mathrm{~m}$ height in July (2017 and 2018), and total and cone dry matter yield (DMY) from plant samples collected in August 2017 and September 2018.

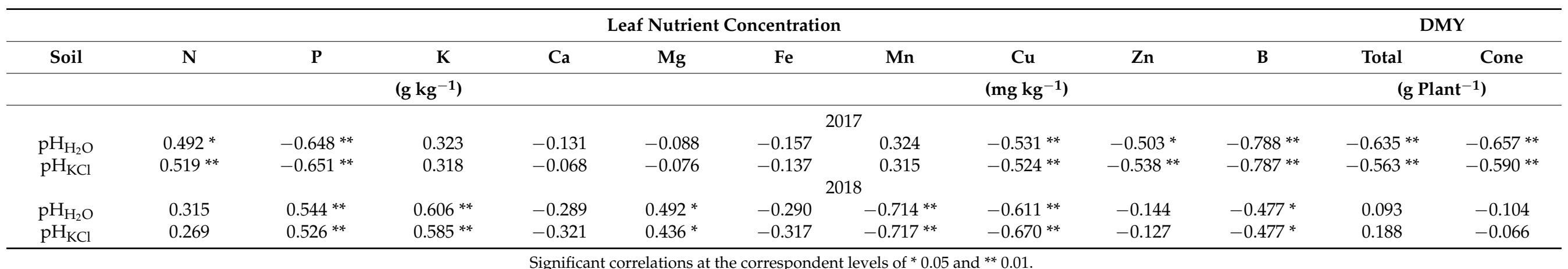




\section{Discussion}

The results of Experiment 1 showed significant differences in some soil properties at different positions along the rows, but not over a continuous gradient. Thus, the results cannot be attributed to the flooding irrigation, but they were probably caused by heterogeneity in spatial variability of important soil constituents such as clay, sand and silt, since it is well-known that soil texture determines many other soil physical and chemical properties [25]. Variations in soil properties were also found when comparing different soil layers. The soil bulk density was higher in the soil surface layer $(0.0-0.1 \mathrm{~m})$, and porosity was found to be higher in the deeper $(0.1-0.2 \mathrm{~m})$, layer. The soil bulk density and porosity in agricultural fields are influenced not only by soil texture but also by external loads which cause soil compaction $[13,26,27]$. In this particular case, it seems that the effects of frequent irrigation and soil tillage prevailed, which may have prevented a proper soil aggregation, leading to an increase in soil bulk density and a reduction in soil porosity on the surface layer which was directly impacted by the cultivator. The variation in soil properties was also significant when comparing fields. The field higher in clay and lower in sand presented significantly higher soil bulk density. Usually, clayey soils tend to have a lower bulk density and higher porosity than sandy soils [28]. However, these results indicate an opposite trend, probably because of the negative effect on soil aggregation and compaction caused by frequent soil tillage. Other studies have also found spatial variability in bulk density and water infiltration on flooded fields caused mainly by tillage practices, particularly when heavy machinery is used [8,29].

The soil samples collected from the ridges showed significantly higher values of extractable $\mathrm{P}$ and $\mathrm{K}$. In the ridges, the conditions for nutrient uptake were poor since they are created every year by soil pushed from the inter-rows, which means that they contain nutrients barely taken up by the plant due to the limited expansion of roots in this position. In addition, in this irrigation system, the water flows from the inter-row to the ridge due to the gradient of water potential caused by the evapotranspiration from the latter and the continuous water supply to the inter-row. This means that nutrients tend to accumulate in the ridge, carried by mass flow, in contrast to what happens in the inter-row, from which nutrients tend to be leached out. Mass flow is the main driving force causing the movement of most nutrients in the soil [30-32]. Thus, soil conductivity was higher in the ridge, due to the increased presence of salts as demonstrated by the increase in CEC. Organic $C$ also appeared higher in the ridge, probably because this zone is not tilled so frequently, which reduces the exposure of organic matter to the heterotrophic microorganisms that cause its oxidation [33]. This zone also contains the remaining bines (those that do not climb) and weeds, which are incorporated into the soil when the ridge is created, which usually represent more debris than that incorporated in the inter-row. B also increased in the ridge, perhaps due to higher levels of organic $C$, which have the ability of retaining $B$ in the soil [34,35].

Soil $\mathrm{pH}\left(\mathrm{H}_{2} \mathrm{O}\right.$ and $\left.\mathrm{KCl}\right)$, base saturation and extractable $\mathrm{Mn}$ were significantly higher in the samples collected in the inter-rows. These results are probably related to the decrease in the potential redox, which may have increased the $\mathrm{pH}$ of the soil [36]. The increase in soil $\mathrm{pH}$ in the inter-rows was probably also related to the increase in the concentration of cation ions, such as $\mathrm{Ca}$ and $\mathrm{Fe}$ [37]. Base saturation increased in the inter-rows probably due to the presence of the divalent cations, less available to move into the ridge by mass flow. The higher concentration of $\mathrm{Mn}$ in the inter-rows might have also been due to the reduction of $\mathrm{Mn}$ that occurred at the beginning of the reduction process. This can occur when the redox potential is still positive [38].

A clear gradient along the rows was not observed for total and cone DMY. These results did not corroborate the hypothesis that flood irrigation is creating a spatial variation in plant performance along the rows. The differences detected in the plants seem to be due to spatial variability in the soil constituents, namely the soil separates which, in turn, influence soil bulk density and porosity. The results from the correlation analysis showed significant and negative relations between total DMY and soil bulk density $(r=-0.706)$ and 
between total DMY and clay content $(r=-0.676)$. In contrast, total DMY and soil porosity at $0.10-0.20 \mathrm{~m}$ correlated significantly and positively $(\mathrm{r}=0.714)$. The soil surface layer presented a higher bulk density, which has already been explained by the effect of irrigation and frequent soil tillage, which reduces the stability of soil aggregates, increasing bulk density and decreasing porosity $[10,26]$. On the other hand, it seems that the higher porosity in the $0.10-0.20 \mathrm{~m}$ layer was an important factor affecting DMY, likely because in the surface layer the diffusion of oxygen to ensure the biological processes of the soil is always easier. Soils with a higher clay content tend to retain more water, decreasing soil aeration which negatively affects the function of root and plant metabolism [13,39]. Under the conditions of this experiment, the clay content in the soil seemed to be negatively associated with hop DMY, mainly because clay is a determinant factor of soil bulk density and porosity, which were identified in this study as determinant factors in crop productivity.

Irrigation also did not cause any relevant gradient in tissue nutrient concentration as detected by the analysis of variance. However, correlation analysis provided some data that deserves to be commented on. Leaf $\mathrm{P}$ was significantly and positively correlated with soil porosity at $0.10-0.20 \mathrm{~m}$, but was negatively correlated with soil bulk density at $0.10-0.20 \mathrm{~m}$ and clay content. Leaf P did not show any consistent gradient along the rows, but was lower in the field presenting a higher soil bulk density and clay content. This reveals that $P$ uptake was enhanced by the increased porosity of the soil at the deeper layer and by the lower clay content. Similarly, on barley (Hordeum vulgare L.) there was reported a reduction in P uptake and yield associated with heavy soil compaction [13]. The higher porosity of soil may have facilitated P root uptake from the deeper layer, which is richer in $\mathrm{P}$, probably due to the increase in the vertical movement of $\mathrm{P}$ as the result of fertilization and flooding as reported by [40]. In turn, the higher clay content may have resulted in higher P adsorption and lower P availability. In contrast, leaf Fe was significantly and negatively correlated with soil porosity at $0.10-0.20 \mathrm{~m}$ depth. Leaf Fe also presented an opposite tendency between fields, decreasing along the rows in the field with a lower clay content and higher soil porosity. This result is probably related to soil reduction conditions, as the availability of Fe decreases when soil oxygen and redox potential increases [37]. Leaf K showed a significant and positive correlation with soil clay content and a negative one with sand content. The availability of $\mathrm{K}$ in the soil is not directly affected by redox potential, but its fixation in 2:1 clay minerals is facilitated by the increase in soil $\mathrm{pH}$ [36]. There has also been reported an antagonistic effect between Fe and $\mathrm{K}$ in paddy fields [41,42], an aspect that may also have influenced these results.

In Experiment 2, the application of lime increased several variables of soil fertility, including $\mathrm{pH}$, but did not significantly increase exchangeable $\mathrm{Ca}$ and CEC. In fact, the rate of lime applied in this experiment was too low to cause important changes to soil properties, as is usually achieved when using high rates of lime [32]. In a previous study, Čeh and Čremožnik [17] applied $2.3 \mathrm{t} \mathrm{lime} \mathrm{ha}{ }^{-1}$ and reported similar results, that is, a reduced effect on soil properties due to the application of lime.

The main effect on the elemental composition of the leaves resulting from the application of lime would have been the significant increase of leaf $\mathrm{P}$ in the first growing season after the lime application. This raised the soil $\mathrm{pH}$ contributing to a reduction in $\mathrm{P}$ fixation, which in acidic soils is due to reactions with $\mathrm{Al}$ and Fe oxides, which precipitate $\mathrm{P}$ as $\mathrm{AlPO}_{4}$ and $\mathrm{FePO}_{4}$ [43].

Total and cone DMY did not increase with the application of lime, but rather showed a decreasing trend. It is generally considered that the optimal $\mathrm{pH}$ for hop growth is between 5.7 and $7.5[15,44]$. In this study, soil $\mathrm{pH}$ was below the lowest value of the reported range, which would have favoured a positive effect on the vegetation. However, the lime application influenced some soil properties, but not enough to have a high impact on the elemental composition of the leaves. In general, the nutrient content of the leaves was found to be within the sufficiency ranges established for hops [45], both in the limed and in the control treatments. Regarding total DMY, a significant interaction between lime 
treatment and field was recorded, which may also have contributed to difficulties in the interpretation of these results.

Correlation analysis, in turn, also did not show coherent trends over the two years of the study. Perhaps the most relevant result was the negative correlation between soil $\mathrm{pH}$ and biomass production in the first year, which again refers to diverse interactions which may have occurred between environmental variables (year) and factors under study (field and liming). The effect of environmental variables on the performance of the hop plant is well known [46-48], although in this study it was not possible to clarify the isolated effects of any of them.

\section{Conclusions}

Irrigation by flooding the space between rows over more than 20 years was not responsible for any gradient in soil properties, plant elemental composition and plant performance, although variations in those variables were found at different positions in the row caused by erratic spatial variability of some constituents of the soil, such as sand, silt and clay. However, irrigation followed by soil tillage on repeated occasions during the growing season seems to have reduced soil porosity and increased soil bulk density in the surface $0.0-0.1 \mathrm{~m}$ soil layer. These variables were found to be related to crop productivity in positive and negative ways, respectively.

This study also showed that the ridge is a point of nutrient accumulation, particularly for those that move more easily in the soil by mass flow, thereby showing also higher conductivity and CEC. The reduced water potential in the ridge created by evapotranspiration is the driving force causing the water flow from the inter-row. Organic $C$ was also higher in the ridge in comparison with the inter-row, probably due to the annual incorporation of weeds and weaker hop bines (those that did not climb) when the ridge is created in early spring.

Although the original soil was acidic, and the application of $1000 \mathrm{~kg} \mathrm{ha}^{-1}$ of lime caused a small increase in $\mathrm{pH}$, this did not lead to other relevant changes in soil properties, nor in plant nutrition status or total and cone DMY. The liming effect might not have been enough to nullify the effects of the interaction between factors that always occur in field experiments.

Author Contributions: Conceptualization, M.Â.R.; methodology, M.A. and S.A.; formal analysis, S.A.; investigation, S.A.; resources, M.Â.R. and M.A.; data curation, S.A.; writing-original draft preparation, S.A.; writing-review and editing, M.Â.R.; supervision, M.Â.R. and M.A.; project administration, M.Â.R.; funding acquisition, M.Â.R. and M.A. All authors have read and agreed to the published version of the manuscript.

Funding: The authors are grateful to the Foundation for Science and Technology (FCT, Portugal) for financial support from national funds FCT/MCTES, to CIMO (UIDB/AGR/00690/2020) and for Sandra Afonso's doctoral scholarship (BD/116593/2016).

Institutional Review Board Statement: Not applicable.

Informed Consent Statement: Not applicable.

Data Availability Statement: No new data were created or analyzed in this study. Data sharing is not applicable to this article.

Conflicts of Interest: The authors declare no conflict of interest.

\section{References}

1. Turner, S.F.; Benedict, C.A.; Darby, H.; Hoagland, L.A.; Simonson, P.; Sirrine, J.R.; Murphy, K.M. Challenges and Opportunities for Organic Hop Production in the United States. Agron J. 2011, 103, 1645-1654. [CrossRef]

2. Rossini, F.; Virga, G.; Loreti, P.; Iacuzzi, N.; Ruggeri, R.; Provenzano, M.E. Hops (Humulus lupulus L.) as a Novel Multipurpose Crop for the Mediterranean Region of Europe: Challenges and Opportunities of Their Cultivation. Agriculture 2021, 11, 484. [CrossRef]

3. Hoque, M. The Way Ahead. In Biotechnology for Sustainable Agriculture; Singh, R.L., Mondal, S., Eds.; Woodhead Publishing: Cambridge, UK, 2018; pp. 375-397. [CrossRef] 
4. Afonso, S.; Arrobas, M.; Rodrigues, M.Â. Soil and Plant Analyses to Diagnose Hop Fields Irregular Growth. J. Soil Sci. Plant Nutr. 2020, 20, 1999-2013. [CrossRef]

5. Hedley, C.B.; Knox, J.W.; Raine, S.R.; Smith, R. Water: Advanced Irrigation Technologies. In Encyclopedia of Agriculture and Food Systems; Van Alfen, N.K., Ed.; Academic Press: Oxford, UK, 2014; pp. 378-406. [CrossRef]

6. Simmonds, M.B.; Plant, R.E.; Peña-Barragán, J.M.; van Kessel, C.; Hill, J.; Linquist, B.A. Underlying Causes of Yield Spatial Variability and Potential for Precision Management in Rice Systems. Precis. Agric. 2013, 14, 512-540. [CrossRef]

7. Cox, C.; Jin, L.; Ganjegunte, G.; Borrok, D.; Lougheed, V.; Ma, L. Soil Quality Changes Due to Flood Irrigation in Agricultural Fields Along The Rio Grande in Western Texas. Appl. Geochem. 2018, 90, 87-100. [CrossRef]

8. Cerdà, A.; Daliakopoulos, I.N.; Terol, E.; Novara, A.; Fatahi, Y.; Moradi, E.; Salvati, L.; Pulido, M. Long-Term Monitoring of Soil Bulk Density and Erosion Rates in Two Prunus persica (L) Plantations Under Flood Irrigation and Glyphosate Herbicide Treatment in La Ribera District, Spain. J. Environ. Manag. 2021, 282, 111965. [CrossRef] [PubMed]

9. González-Méndez, B.; Webster, R.; Fiedler, S.; Siebe, C. Changes in Soil Redox Potential in Response to Flood Irrigation with Waste Water in Central Mexico. Eur. J. Soil Sci. 2017, 68, 886-896. [CrossRef]

10. Batey, T. Soil Bompaction and Soil Management-A Review. Soil Use Manag. 2009, 25, 335-345. [CrossRef]

11. Shapiro, C.A.; Elmore, R.W. Agricultural Crops. In Encyclopedia of Applied Plant Sciences, 2nd ed.; Thomas, B., Murray, B.G., Murphy, D.J., Eds.; Academic Press: Oxford, UK, 2017; pp. 1-8. [CrossRef]

12. Arriaga, F.J.; Guzman, J.; Lowery, B. Conventional Agricultural Production Systems and Soil Functions. In Soil Health and Intensification of Agroecosytems; Al-Kaisi, M.M., Lowery, B., Eds.; Academic Press: Cambridge, MA, USA, 2017 ; pp. 109-125. [CrossRef]

13. Nawaz, M.F.; Bourrié, G.; Trolard, F. Soil Compaction Impact and Modelling. A Review. Agron. Sustain. Dev. 2013, 33, 291-309. [CrossRef]

14. Indoria, A.K.; Sharma, K.L.; Reddy, K.S. Hydraulic properties of soil under warming climate. In Climate Change and Soil Interactions; Prasad, M.N.V., Pietrzykowski, M., Eds.; Elsevier: Amsterdam, The Netherlands, 2020; pp. 473-508. [CrossRef]

15. Sirrine, J.R.; Rothwell, N.; Lizotte, E.; Goldy, R.; Marquie, S.; Brown-Rytlewski, D. Sustainable Hop Production in the Great Lakes Region. Ext. Bull. E-3083 2010. Available online: https:/ / www.uvm.edu/sites/default/files/media/Sirrine-Sustainable-HopProduction-in-the-Great-Lakes-Region.pdf (accessed on 13 April 2019).

16. Gent, D.H.; Sirrine, J.R.; Darby, H.M. Nutrient Management and Imbalances. In Field Guide for Integrated Pest Management in Hops; Washington Hop Commission: Moxee, WA, USA, 2015; pp. 98-100.

17. Čeh, B.; Čremožnik, B. Soil pH and Hop (Humulus lupulus) Yield Related to Liming Material Rate. Hmelj. Bilt. 2015, $22,49-57$.

18. Seng, V.; Bell, R.W.; Willett, I.R. Effect of Lime and Flooding on Phosphorus Availability and Rice Growth on Two Acidic Lowland Soils. Commun. Soil Sci Plant Anal. 2006, 37, 313-336. [CrossRef]

19. Sadiq, A.A.; Babagana, U. Influence of Lime Materials to Ameliorate Acidity on Irrigated Paddy Fields: A Review. Acad. Res. Int. 2012, 3, 413.

20. Shi, L.; Guo, Z.; Liang, F.; Xiao, X.; Peng, C.; Zeng, P.; Feng, W.; Ran, H. Effect of Liming with Various Water Regimes on Both Immobilization of Cadmium and Improvement of Bacterial Communities in Contaminated Paddy: A Field Experiment. Int. J. Environ. Res. Public Health 2019, 16, 498. [CrossRef] [PubMed]

21. Rowell, D.L. Soil Science: Methods E Applications, 1st ed.; Longman Group UK Ltd.: Harlow, UK, 1994; p. 368. [CrossRef]

22. Van Reeuwijk, L. Procedures for soil analysis (International Soil Reference and Information Centre). Tech. Pap. $2002,9,120$.

23. Lakanen, E.; Erviö, R. A Comparison of Eight Extractants for the Determination of Plant Available Micronutrients in Soils. Acta Agric. Fenn. 1971, 123, 223-232.

24. Walinga, I.; Van Vark, W.; Houba, V.; Van der Lee, J. Soil and Plant Analysis, Part 7: Plant Analysis Procedures; Wageningen Agricultural University: Wageningen, The Netherlands, 1989.

25. Delgado, A.; Gómez, J.A. The Soil. Physical, Chemical and Biological Properties. In Principles of Agronomy for Sustainable Agriculture; Villalobos, F.J., Fereres, E., Eds.; Springer International Publishing: Cham, Switzerland, 2016; pp. 15-26. [CrossRef]

26. Hamza, M.A.; Al-Adawi, S.S.; Al-Hinai, K.A. Effect of Combined Soil Water and External Load on Soil Compaction. Soil Res. 2011, 49, 135-142. [CrossRef]

27. Alaoui, A.; Rogger, M.; Peth, S.; Blöschl, G. Does Soil Compaction Increase Floods? A Review. J. Hydrol. 2018, 557, 631-642. [CrossRef]

28. Chaudhari, P.R.; Ahire, D.V.; Ahire, V.D.; Chkravarty, M.; Maity, S. Soil Bulk Density as Related to Soil Texture, Organic Matter Content and Available Total Nutrients of Coimbatore Soil. Int. J. Sci. Res. Publ. 2013, 3, 1-8.

29. Green, T.R.; Ahuja, L.R.; Benjamin, J.G. Advances and Challenges in Predicting Agricultural Management Effects on Soil Hydraulic Properties. Geoderma 2003, 116, 3-27. [CrossRef]

30. Lambers, H.; Chapin, F.S.; Pons, T.L. Mineral Nutrition. In Plant Physiological Ecology; Lambers, H., Chapin, F.S., Pons, T.L., Eds.; Springer: New York, NY, USA, 2008; pp. 255-320. [CrossRef]

31. Comerford, N.B. Soil Factors Affecting Nutrient Bioavailability. In Nutrient Acquisition by Plants: An Ecological Perspective; BassiriRad, H., Ed.; Springer: Berlin/Heidelberg, Germany, 2005; pp. 1-14. [CrossRef]

32. Weil, R.R.; Brady, N.C. The Nature and Properties of Soils, 15th ed.; Global Edition: London, UK, 2017.

33. Liu, X.; Herbert, S.; Hashemi, A.; Zhang, X.; Ding, G. Effects of Agricultural Management on Soil Organic Matter and Carbon Transformation-A Review. Plant. Soil Environ. 2006, 52, 531. [CrossRef] 
34. Goldberg, S. Reactions of Boron with Soils. Plant Soil 1997, 193, 35-48. [CrossRef]

35. Das, A.K.; Purkait, A. Boron Dynamics in Soil: Classification, Sources, Factors, Fractions, and Kinetics. Commun. Soil Sci. Plant Anal. 2020, 51, 2778-2790. [CrossRef]

36. Husson, O. Redox Potential (Eh) and $\mathrm{pH}$ as Drivers of Soil/Plant/Microorganism Systems: A Transdisciplinary Overview Pointing to Integrative Opportunities for Agronomy. Plant Soil 2013, 362, 389-417. [CrossRef]

37. Osman, K.T. Soils: Principles, Properties and Management, 1st ed.; Springer: Dordrecht, The Netherlands, 2013.

38. George, E.; Horst, W.J.; Neumann, E. Adaptation of Plants to Adverse Chemical Soil Conditions. In Marschner's Mineral Nutrition of Higher Plants; Marschner, P., Ed.; Elsevier: Amsterdam, The Netherlands, 2012; pp. 409-472.

39. Pezeshki, S.R.; DeLaune, R.D. Soil Oxidation-Reduction in Wetlands and its Impact on Plant Functioning. Biology 2012, 1, 196-221. [CrossRef]

40. Tian, J.; Dong, G.; Karthikeyan, R.; Li, L.; Harmel, R. Phosphorus Dynamics in Long-Term Flooded, Drained, and Reflooded Soils. Water 2017, 9, 531. [CrossRef]

41. Chen, J.; Xuan, J.; Du, C.; Xie, J. Effect of Potassium Nutrition of Rice on Rhizosphere Redox Status. Plant Soil 1997, 188, 131-137. [CrossRef]

42. Kundu, D.; Neue, H.; Singh, R. Iron and Potassium Availability to Rice in Tropudalf and Sulfaquept as Influenced by Water Regime. J. Indian Soc. Soil Sci. 2001, 49, 130-134.

43. Havlin, J.L.; Tisdale, S.L.; Nelson, W.L.; Beaton, J.D. Soil Fertility and Fertilizers: An Introduction to Nutrient Management, 8th ed.; Pearson: Boston, MA, USA, 2014.

44. Gingrich, C.; Hart, J.; Christensen, N. Fertilizer Guide 79; Oregon State University, Extension Service: Corvallis, OR, USA, 1994.

45. Bryson, G.; Mills, H.; Sasseville, D.; Jones, J.B., Jr.; Barker, A. Plant. Analysis Handbook III: A Guide to Sampling, Preparation, Analysis and Interpretation for Agronomic and Horticultural Crops; Micro-Macro Publishing: Athens, GA, USA, 2014.

46. Marceddu, R.; Carrubba, A.; Sarno, M. Cultivation Trials of Hop (Humulus lupulus L.) in Semi-Arid Environments. Heliyon 2020, 6, e05114. [CrossRef]

47. MacKinnon, D.; Viljem, P.; Čeh, B.; Naglič, B.; Pavlovic, M. The Impact of Weather Conditions on Alpha-Acid Content in Hop (Humulus lupulus L.) cv. Aurora. Plant. Soil Environ. 2020, 66, 519-525. [CrossRef]

48. Rossini, F.; Virga, G.; Loreti, P.; Provenzano, M.E.; Danieli, P.P.; Ruggeri, R. Beyond Beer: Hop Shoot Production and Nutritional Composition under Mediterranean Climatic Conditions. Agronomy 2020, 10, 1547. [CrossRef] 